\title{
THE LAW OF FOREIGN TRADE IN THE PEOPLE'S REPUBLIC OF BULGARIA
}

\author{
IVAN SIPKov*
}

I

Background: The Legat Framework

\section{A. Establishment of the Foreign Trade Monopoly}

Prior to the advent of the present government on September 9, I944, the export of Bulgarian products and the import of foreign goods were primarily within the sphere of private activity and were carried on by commercial firms and organizations. In accordance with the legal framework then in existence, individual citizens had the right freely to engage in commercial activities and, in particular, to engage in transactions involving foreign trade with freedom to form foreign trade organizations as well. Any interference by the government was confined to measures aimed at regulating and supporting the export-import activity of these commercial enterprises.

After the establishment of the present government and in the course of its consolidation, the foreign trade of the country underwent profound changes. The Bulgarian legislation in this field was mainly the result of the change in the form of government. As is well known, during the final stages of World War II, as a result of Soviet military occupation and political influence and the coup d'état of September 9, 1944, Bulgaria was politically, economically, and socially reorganized into a people's democracy. All measures directed to the reorganization purportedly sprang from an economic philosophy based on the establishment of a governmentplanned economy and the nationalization of the economy, as well as from a sociallegal theory patterned after that subscribed to by the Soviet Union. Along this line foreign trade was declared a government monopoly as an inseparable part of state sovereignty.

All this has been gradually achieved by virtue of a series of legislative enactments and administrative measures aimed at abolishing all private initiative and all private organizations engaged in foreign trade activities. Thus, at the early stage of development, to use the words of Petko Stainov, professor of law at Sofia University, "the government monopoly of foreign trade was established on the basis of the legislation in effect taken in its entirety." According to Stainov, the explanation for the establishment of a government monopoly of foreign trade is that "[conducting the] foreign trade relations of the People's Republic of Bulgaria

\footnotetext{
- Assistant Chief, European Law Division, Law Library, Library of Congress; Co-editor, InTERnationar. Journal of Law Librariés.

${ }^{1}$ P. Stainov, Rŭkovodstvo po administrativino pravo (Manual of Administrative Law) ${ }^{8} 4$ (1950).
} 
[has] ... been transformed into a government function and [has become] a government task."2

The Constitution of December 6, I947, itself, gave the government the authority "to nationalize fully or partially branches of industry, trade, transport, and credit" (section 10, paragraph 2), and further declared that "foreign and domestic trade shall be directed and controlled by the State" (section 13 ). ${ }^{3}$ Paragraph 2 of section I3 provides that "the State may reserve to itself the exclusive right to produce and trade in any goods which are of essential importance to the national economy and the needs of the people."

The crucial step toward the establishment of a government monopoly, however, was taken by the Law of December 27, 1948, which created a separate Ministry of Foreign Trade and empowered it "to exercise the foreign trade of the country." Although this Law did not expressly use the term "government monopoly" in this field of economic activity, legal writers of present-day Bulgaria consider it the law on which the government monopoly of foreign trade was based. It was perhaps in the new section $\operatorname{I2I}(b)$ of the Criminal Code of 195I (amendment of February 10, 1956) that the term "government monopoly of foreign trade" was first expressly used in a legal text:

Whoever violates the resolutions and decisions of the Council of Ministers concerning the monopoly of foreign trade shall be punished by deprivation of liberty for up to 3 years. (Emphasis added.) ${ }^{5}$

The special Law on Foreign Trade of December 5, 1969, now in force, states that the foreign trade activity in the People's Republic of Bulgaria "is realized on the basis of the government monopoly of foreign trade" (section 3$)^{6}$ The same Law further expressly excludes in section II, paragraph 2, physical persons and individual citizens from conducting foreign trade activities. And of course, the recent Constitution of May 16, 197r, made it, in its section 29, paragraph 2, a constitutionally established principle that "foreign trade is an exclusive right of the State."7 Legal writers interpret these provisions as attaching the monopoly to the "sovereign rights of [the Bulgarian] socialist state."8

\section{B. Sources of Foreign Trade Law}

The Bulgarian legislation now in effect does not offer a single system of gen-

\footnotetext{
Id. at 183 .

${ }^{3}$ i947 Dŭrzhaven Vestnik (Bulgarian Official Law Gazette) No. 284. This Gazette was called Dŭrzhaven Vestnik until November 30, I950; from December 1, 1950, until January 1, 1963, it was titled Izvestila na Prezidiuma na Narodnoto Sŭbranie; on January 1 , 1963, the former title was restored and is currently used [hereinafter cited as DV and IPNS].

1948 DV No. 279.

I956 IPNS No. 12.

${ }^{\circ} 1969$ DV No. 94. Regulation Implementing the Law on Foreign Trade, 1970 DV No. 10x.

I97I DV No. 39.

${ }^{8}$ Penkov, Zakonŭt za vĭnshnata tŭrgoviia (The Law on Foreign Trade), 18 VŭNsHNA Tŭrgovin No. I (1970), at I.
} 
eral rules governing the international commerce of the country. Professor Zhivko Stalev stated that "when we speak of the law of foreign trade [LFT], we think not of a separate branch of our legal system, but of an assembly of legal rules belonging to various legal branches." In other words, the body of legal regulations pertaining to foreign trade consists of a great number of laws and decrees as well as of individual provisions scattered throughout the general legislation. In most instances, major acts dealing with this matter are of very recent date.

The Constitution of May I6, I971, contains several provisions directly related to this particular field of economic activity, and the Law on Foreign Trade of December 5, 1969, and its Implementing Regulation of December 22, 1970, set forth the basic principles regarding government foreign trade policy and monopoly. Relevant in this connection are the Regulation Concerning Government Economic Organizations of December II, I970; the Regulation Concerning the Organization, Administration, and Control of Foreign Trade of November I9, I968; the Regulation Concerning the Registration of Foreign Trade Enterprises in the Register at the Chamber of Commerce of June 6, 1969; the Model Charter of a Foreign Trade Company of February 7, I967; the Ordinance Concerning Firms Abroad with Bulgarian Participation of February I4, I969; the Order No. I04 Concerning Import-Export Licenses of March 25, I969, as well as several other acts related to the Chamber of Commerce, the Bulgarian Foreign Trade Bank, the Foreign Trade Arbitration Tribunal and the like.

\section{II}

\section{The Foreign Trade Mechanism}

\section{A. Administration of the Foreign Trade Monopoly}

Under the Bulgarian legislation now in force, the government monopoly of foreign trade affords the State the exclusive right (a) to determine the foreign trade policy of the country; (b) to plan, organize, direct, and control foreign trade activities; (c) to establish government economic organizations with the task of conducting foreign trade activities; (d) to grant to government, cooperative, and other organizations the right to conduct foreign trade activities and to determine the object and conditions of their activities; (e) to authorize the participation of Bulgarian organizations in economic activities abroad; ( $f$ ) to evaluate the possibility of and to establish the conditions for foreign enterprises and firms conducting commercial and other economic activities in the country; (g) to establish the mechanisms for conducting foreign trade activities; and (h) to direct the participation of the country in the international division of labor for the purpose of conducting an effective foreign trade for the national economy. ${ }^{\mathbf{1 0}}$

\footnotetext{
${ }^{0}$ Stalev, Pravo na vĭnshnata tïrgoviia (The Law of Foreign Trade), 15 VŭNsHNa TŭRgovia No. 6 (1967), at Io.

${ }^{10} \mathrm{Law}$ on Foreign Trade, $\S 3$.
} 
Section 2 of the basic Law on Foreign Trade defines "foreign trade activities" as

all transactions of the export and import of goods, of re-export, as well as of transport, representation, foreign trade advertising and the propaganda connected with them, of granting copyrights and the rights to inventions, trademarks and industrial designs, and all transactions in the field of technical experiments and other activities connected with international economic relations.

Bulgarian legal writers are of the opinion that the government monopoly of foreign trade, however, is not limited to the conclusion and realization of foreign trade transactions, but that it also includes international payments. ${ }^{11}$ Therefore, the state monopoly includes the monopoly of transactions involving foreign exchange. ${ }^{12}$

Pursuant to the principle that foreign trade is a government monopoly which represents an inseparable part of state sovereignty, the exercise of this right, as a rule, is under the overall general direction and supervision of the Council of Ministers, but within the direct jurisdiction of the Ministry of Foreign Trade. Thus, this Ministry is entrusted with the power to direct, plan, coordinate, and control the entire foreign trade activity of the country by coordinating it within the national economic plan, by entering into bilateral international commerce agreements, and by administering the licensing of exports and imports.

\section{B. Foreign Trade Organizations}

The doctrine that foreign trade monopoly is a sovereign function of the People's Republic of Bulgaria does not, however, mean that the State assumes the role of a merchant, that it itself engages in foreign trade activities. The State does not act in the capacity of a trader but it effectuates foreign trade transactions through government economic enterprises, the rights and responsibilities of which are defined by the Council of Ministers. ${ }^{13}$ Thus, the development of the country's international commerce is entrusted to special foreign trade organizations (vĭnshnotürgovski organizatsii) which are selected from among the various government economic combines, enterprises, societies, cooperatives, and the like.

These economic bodies are legal entities established, reorganized, and abolished in accordance with sections $63-65$ of the Regulation Concerning Government Economic Organizations of December II, 1970. These entities operate on the basis of economic self support (samoizdrüzhka) and on the principle of business accounting (stopanska smetka). ${ }^{14}$ This means that they are liable for their debts and obligations

\footnotetext{
${ }^{11}$ P. Penkov, Vŭnshana tŭrgovila na N.R. Bŭlgarita. Zakoni, postanovlenila, I dR. (Foreign Trade of the P.R. of Bulgaria. Laws, Regulations, etc.) 30 (1969).

12 Regulation No. 986 of the Council of Ministers Concerning Transactions wtih Forcign Currency of December 22, 1952. 1963 DV No. I.

${ }^{13}$ Regulation Concerning Government Economic Organizations, $\S 2$, \2. x970 DV No. 98. This section defines government economic enterprises as organizations established on government ownership which (a) with the efforts of a labor collective, conduct economic activities; (b) work on economic account pursuant to the uniform plan for socio-economic development of the country; and (c) are legal entities.

${ }^{14}$ I970 DV No. 98.
} 
to the extent of the assets allocated to them by the State. That is to say that they are not liable for the debts and obligations of the State and other organizations, and that the State is not responsible for the obligations of foreign trade organizations. In short, these are separate legal entities capable of suing and being sued, and acquiring and owning property. However, they give account for and distribute the proceeds of their activities in accordance with the Ordinance on the Formation and Distribution of the Profits Achieved by Government Economic Organizations of December 15, I970..$^{15}$

Since transactions, in the meaning of section 2 of the Law on Foreign Trade, may be concluded only by foreign trade organizations, no ministries, administrative departments, or other government economic enterprises may conduct negotiations, assume obligations, or conclude foreign trade contracts, unless approved by the Council of Ministers. Furthermore, foreign trade organizations may, independently or through partnership, participate in firms abroad. For the preparation and conclusion of foreign trade transactions, these organizations are obliged to keep in contact with the Bulgarian Trade Agencies abroad and to ask their assistance.

Because the number of foreign trade organizations has increased tremendously in recent years, the government has provided for their registration in a special Register. This Register, as specified in the Regulation Concerning the Registration of Foreign Trade Enterprises in the Register at the Chamber of Commerce of June 6, $1969,{ }^{16}$ includes the following information: the title of the organization, the constitutive act on the basis of which it was given the right to conduct foreign trade activities, the nomenclature of the goods, the amount of the funds determined by the by-laws of the organization, and the names of the persons who represent it and the scope of their authority. The Chamber of Commerce announces the registration in the official law gazette of the country, Dürzhaven Vestnik, and in the magazine, Bülgarska Vünshna Türgoviia. The Register is open to the public and certified copies of its contents may be obtained. The Chamber may also reject registration, but the rejection may be subject to appeal to the Foreign Trade Ministry whose decision is final.

At present, the conduct of the country's international commerce is entrusted to three types of foreign trade organizations: (a) government foreign trade enterprises-the oldest and most prevalent form of organization conducting the greatest volume in quantity and value, (b) cooperative organizations and unions, and (c) companies with limited liability (druzhestva s ogranichena otgovornost), established in 1966, members of which may be enterprises engaged in activities connected with that of the company. ${ }^{17}$ The Model Charter of a Foreign Trade Company of February 7, r967, states that permission by the Council of Ministers is necessary for its creation, but its by-laws are to be approved by the Minister of Foreign

\footnotetext{
${ }^{15} 1970$ DV No. 99.

20 1969 DV No. 44.

${ }^{17}$ Penkov, supra note $\mathrm{II}$, at 52-55.
} 
Trade, and its activities are under the direction and control of this Ministry. ${ }^{18}$ It may conclude contracts, organize branches, agencies and bureaus at home and abroad, employ commercial propaganda and advertisements, participate in international fairs and exhibitions, and, with the permission of the Council of Ministers, create and participate in mixed enterprises abroad. Upon registration of the company in the People's Court and the announcement thereof in Dirzhaven Vestnit, it becomes a legal entity, owns its capital consisting of the shares deposited by its members, who are responsible up to the amount of their share, and functions on the principles of economic accountability (stopanska smetka) and self support (samoizdrŭzhka).

In his analysis of the three categories of foreign trade organizations, the Deputy Minister of Foreign Trade, Ivan Golomeev, states that, even though they are independent legal entities, they may be subordinated to ( $I$ ) a respective economic combine developing a similar type of activity, (2) a foreign trade company serving several combines, or (3) an economic organization specializing in foreign trade activities. $^{10}$

(a) Golomeev lists the following foreign trade enterprises subordinated to a respective economic combine (considered a prevailing form): Agramachinaimpelss to Government Economic Combine (GEC) Agromashina; Avtoimpeks to GEC Avtoprom; Izotimpeks to GEC Izot; Rodopaimpeks to GEC Rodopa; Bülgarplodeksport and Bülgarkonserv to GEC Bülgarplod; Bülgartabak to GEC Bülgarski Tiutiuni; Vinimpeks to GEC Vinprom; and others.

(b) In the last several years, Golomeev writes, the number of foreign trade companies has increased tremendously. Almost all the export activity of the country now is carried out by foreign trade enterprises subordinated to respective economic combines or companies of several combines. Such are: Khraneksport with members GEC Zürneni khrani and GEC Bülgarska zakhar; Industrialimport with members GEC Tekstil, GEC Rila, GEC Pirin and GEC Stǔklo i fina keramika; Mashinoeksport with members GEC ZMM, GEC Metalkhim, GEC Bitovo mashinostroene and GEC Metaloleene; Eletroimpeks with members GEC Elprom and GEC Resprom; Tsiment $i$ mramor with members GEC Tsiment $i$ stroitelna keramika and GEC Kamenna promishlenost $i$ stroitelni izdeliia; and others.

(c) In addition to these forms, a new category of foreign trade organization was created, the activities of which have a specific or a more specialized nature. Each conducts export on its own account and only in individual cases on the account of the combines, so that the object of their activities is not necessarily that of any combine. Golomeev mentions a few of this form: Tekhnoimpeks, Interpred, Tekhnoiksportstroi, Tekhnoimpeks, as well as those exporting the products of the

\footnotetext{
${ }^{18}{ }_{1967}$ DV No. $\mathrm{rr}$, as amended $1967 \mathrm{DV}$ No. 32.

${ }^{10}$ Golomeev, Roliata $i$ miastoto na vïnshnotürgovskata organizatsiia pri kontsentratsiiata na stopanskata deinost (Role and Place of the Foreign Trade Organization in the Concentration of Economic Activities), rg VŭNshina Tŭrgovir No. 2 (197I), at 2-5.
} 
industrial combines and labor-industrial cooperatives, Koopimpeks, Bülgarkoop, and others.

In its official publication, the present government presents a complete list of all Bulgarian foreign trade organizations, agencies, institutes, and so on, as of March Io, 1970. ${ }^{20}$ It divides them into three groups: (a) economic combines and the foreign trade enterprises attached to them; (b) government and cooperative foreign trade enterprises, societies, and organizations; and (c) banks and other administrative agencies and institutes.

\section{Foreign Trade Agencies Abroad}

As noted above, the Ministry of Foreign Trade conducts the government foreign trade policy under the general direction and supervision of the Council of Ministers and, in accordance with the principle of the government monopoly of foreign trade, directs, plans, coordinates, and controls all foreign trade activities of the country through government foreign trade organizations. ${ }^{21}$ The Ministry of Foreign Trade is, however, assisted in the development of foreign trade and other economic relations of the People's Republic of Bulgaria by commercial representatives abroad (türgovski predstavitelstva) as organs of this Ministry, ${ }_{2}^{22}$ but without the right to conclude trade transactions in their name and on their account. ${ }^{23}$ They are established or abolished by decision of the Council of Ministers and are attached to the staff of the Bulgarian diplomatic missions acting under the general direction and supervision of the person in charge of the Bulgarian diplomatic mission. They may also be set up as independent bodies. The foreign trade agencies and the foreign trade agent (türgouski predstavitel) are members of the diplomatic mission of Bulgaria and enjoy diplomatic privileges and (judicial) immunity. The foreign trade agent may conclude commercial transactions and other acts on behalf of, and for the account of, the Bulgarian foreign trade organizations upon their explicit authorization, free of charge. Their activities and relations with the local authorities and business firms are carried out in accordance with the legislation of the country, the provisions of international law, and international agreements. Furthermore, the domestic government combines, enterprises and other organizations, which have original authorization by the Council of Ministers to conduct foreign trade activities, may, with the permission of the Ministry of Foreign Affairs, open bureaus abroad for representation, service, advertisement, transport, construction, freight, insurance, stores, restaurants, and so forth, connected with the

\footnotetext{
${ }^{20}$ Vŭnshna Tŭrgovita na N.R. BŭlgariIa (Foreign Trade of the P.R. of Bulgaria) 344-56 (I970).

${ }^{21}$ Law on Foreign Trade, $\$ \S 4-5$.

${ }^{22} I d$., $\S 6$.

${ }^{28}$ According to V.G. Khristoforov, they are not legal entities. Khristoforov, Praven statut $i$ funktsii na türgovskite predstavitelstva (Status and Functions of Trade Representatives), PRAvNI vŭprosi NA vŭnshnata tŭrgovita Na N.R. Bŭlgarita (Legal Problems of the Foreign Trade of the P.R. of Bulgaria) 37 (1963).
} 
foreign trade activities. However, they act under the general direction and control of the foreign trade agent. ${ }^{24}$

The main functions of a foreign trade agency abroad are threefold: (I) commercial-political-to conduct the foreign trade policy, representing the interests of the country abroad in regard to foreign trade and other economic problems; (2) research-information-to study the economy of the market in a foreign country, to inform the Ministry of Foreign Trade and foreign trade organizations, and to organize advertising activities; and (3) commercial-operational-to assist the foreign trade organizations in the preparation and conclusion of foreign trade transactions, although they may not conclude such transactions in their own name and on their own account, unless they have special authorization to do that. ${ }^{25}$ All Bulgarian foreign trade agencies abroad, as of March I970, are listed in the official government publication, Vünshna türgoviia na $N$. R. Bülgarïa.$^{26}$

\section{Firms Abroad with Bulgarian Participation}

For the purpose of expanding the economic links with other countries, the Bulgarian government took a series of measures, among which is the formation of foreign local firms with capital participation of Bulgarian foreign trade enterprises. The Regulation Concerning Government Economic Organizations of December II, I970, contains a general provision that a Bulgarian enterprise may, with permission of the Committee for Economic Coordination, establish a society (druzhestvo) with the participation of foreign legal and physical persons and with its seat at home or abroad. ${ }^{27}$ The operation of this type of commercial society is regulated by the Ordinance Concerning Firms Abroad with Bulgarian Participation of February I4, $1969,{ }^{28}$ and approved by special Regulation No. 9 of the Council of Ministers of January 16, I969. ${ }^{29}$ Such firms may be established only by government and cooperative economic organizations which are authorized by the Council of Ministers to exercise foreign trade activities and which are given permission to establish such firms. These firms are economic enterprises with an independent budget (balans) which have their seats abroad. In short, they are legal entities with a basic capital, entirely or partially in the ownership of the Bulgarian government or a cooperative economic enterprise.

The legal status of a firm abroad with Bulgarian participation is to be determined by the laws of the country in which it has been registered. However, this regime must be in accordance with the provisions of the Ordinance. All the shares, dividends, and other documents which express the Bulgarian capital participation in these firms are in the ownership of the Bulgarian foreign trade enterprise, re-

\footnotetext{
"Law on Foreign Trade, 5 Io.

${ }^{25}$ Regulation Implementing the Law on Foreign Trade, $\$ 200$.

${ }^{96}$ VŭNSHiNa tŭrgovita NA N.R. BŭLgarita, supra note 20, at 357-58.

${ }^{27}$ Regulation Implementing the Law on Foreign Trade, \$35, 93 .

${ }^{38}$ 1969 DV No. I3.

${ }^{20} \mathrm{Id}$.
} 
gardless of whether they are registered in their name, or in the name of individual natural persons or their representatives. If the Bulgarian participation exceeds roo,000 (currency) leva, ${ }^{30}$ the request must be considered by the Committee for Economic Coordination at the Council of Ministers. All expenses covered through transfer of leva are to be made through the Bulgarian Foreign Trade Bank. The final conclusion of the contract, registration, and announcement of the firm are to be made in accordance with the legislation of the country where it is located.

The establishment of a firm abroad with Bulgarian participation is always subject to one basic condition: the unconditional approval of the Bulgarian partner in making valid decisions. Bulgarian participation in the executive board is also required, and, in case of collective representation, one of representatives who has the right to sign must be a Bulgarian. Firms abroad with Bulgarian participation may conclude commercial contracts with Bulgarian and foreign business organizations as well as with the Bulgarian enterprise which participates in the firm abroad. A foreign firm, even though it has Bulgarian participation, is not a branch but an independent legal entity which conducts its affairs on a contractual basis. The Ministry of Foreign Trade maintains a file of all firms abroad with Bulgarian participation.

\section{E. Chamber of Commerce}

Upon the approval of its Ustav (Statute) of February 4, I952, the Council of Ministers established a Chamber of Commerce, a public institution having the status of a juridical person. The Chamber has its seat in Sofia. From the point of view of its organization, the Chamber is placed outside the administration, but under the general supervision, of the Ministry of Foreign Trade. ${ }^{31}$ According to the Ustav, it is composed of regular and corresponding members. The regular members are the individual ministries, all government enterprises for export and import, and various other establishments, cooperatives, and banks, while the corresponding members are drawn from experts in foreign trade.

Acting on the basis of economic accountability, the Chamber of Commerce has the task of assisting the development of commercial relations between Bulgaria and commercial and other economic organizations, institutions, and firms abroad, of studying the economic life of the foreign countries, of arranging Bulgaria's participation in international trade fairs, of informing foreign countries about Bulgarian exports (for which purpose it publishes books, pamphlets, magazines, and periodicals), ${ }^{32}$ of registering foreign trade organizations, of applying abroad for approval

\footnotetext{
${ }^{30}$ The official exchange rate in I97I was I.I7 Bulgarian leva per U.S. dollar. I97I PICx's CuRRENCY YEARBOOR 85 (I97I).

${ }^{82}$ The Statute of the Bulgarian Chamber of Commerce is published in 1957 IPNS No. 64. It was approved by Resolution No. rog of the Council of Ministers of February 4, I952, and Decision No. 379 of the Council of Ministers of April 20, I967. It was amended by a Decision of the General Mecting of the members of the Chamber, held on June I9, 1964. See Penkov, supra note Ix, at 86.

${ }^{32}$ The Chamber of Commerce publishes a periodical entitled BŭLgarska Vŭnstans Tŭrgovira (Burgarian Foreign TrAde) in five languages (English, French, German, Russian, and Spanish). In addi-
} 
of patents for Bulgarian inventions, and, upon request, of settling disputes between local and foreign commercial firms through the Foreign Trade Arbitration Tribunal which is attached to it.

\section{F. Banks Serving Foreign Trade}

The development of foreign trade and the expansion of international banking operations necessitated the creation of a special banking institute to serve the foreign trade enterprises. In I964, upon approval of its charter by the government, ${ }^{33}$ the Bulgarian Foreign Trade Bank was set up as a joint-stock company (aktsionerno druzhestvo) with a basic capital of 40,000,000 leva divided into 4,000 shares at I0,000 leva each. ${ }^{34}$ These shares are holder's name-bearing shares and are entered in the books of the shareholders. Each share gives one vote and brings dividends. This bank is the only one in the country which handles all banking operations connected with foreign trade including credits and loans, with the exception of the Marine Commercial Bank, established in Ig68, which serves the enterprises of the Bulgarian Sea Fleet. ${ }^{35}$ The Marine Commercial Bank is a joint-stock company coordinating its international operations with the Bulgarian National Bank and the Bulgarian Foreign Trade Bank. Its capital is 20,000,000 leva divided into 2,000 shares at I0,000 leva each.

According to its charter, the Bulgarian Foreign Trade Bank is a legal entity with its seat in Sofia and is responsible for its own properties (assets). It is not responsible for the obligations of the State or its shareholders and, conversely, the State and its shareholders do not accept liability for obligations incurred by the Bank. However, it has the right to open branches and agencies, both at home and abroad, to maintain representatives there, and to guarantee the secrecy of the operations, accounts, and deposits of its clients. Disputes between the Bank and foreign firms and persons, if not otherwise provided, are adjudicated by the Sofia City Court.

\section{G. Foreign Trade Insurance and International Transportation}

Pursuant to section 5 of the Law to Repeal the Commercial Code and the Law on the Companies with Limited Liability, Regulation No. 253 of the Council of Ministers of July $3 \mathrm{x}, \mathrm{x} 96 \mathrm{x},{ }^{36}$ established a Bulgarian Foreign Insurance and Reinsurance Company "Bulstrad," a joint-stock company with its seat in Sofia and a capital of 4,000,000 leva divided into 4,000 holder's name-bearing shares at 1,000 leva each. ${ }^{37}$ The company may open branches and agencies both within the Republic and abroad, and may participate in the creation of insurance and re-insurance

\footnotetext{
tion, the Ministry of Foreign Trade has its own publication entitled Vŭnshina Tŭncovila (Fonejen Trade), in Bulgarian language only.

${ }^{33}$ Charter of the Bulgarian Foreign Trade Bank, 1964 DV No. Ig.

"See note 30 supra.

${ }^{35}$ Charter of the Marine Commercial Bank, I968 DV No. 53.

${ }^{30}$ Penrov, stipra note $\mathrm{II}$, at 72 .

37 The Charter of "Bulstrad" is published in I96r DV No. 8r.
} 
companies outside the borders of the country. Disputes involving insurance contracts with enterprises and persons abroad, if the contract does not provide otherwise, are to be adjudicated before the Sofia City Court. Disputes between the company and domestic enterprises or persons are under the jurisdiction of the same court. Bulgarian legal writers are of the opinion that these cases should be transferred to the Foreign Trade Arbitration Tribunal at the Bulgarian Chamber of Commerce. ${ }^{38}$

International transportation connected with foreign trade is within the jurisdiction of a special transport establishment, the Government Economic Enterprise, DESPRED, which provides services in accordance with tariffs or by contract. ${ }^{39}$

\section{III}

\section{Foreign Trade Transactions}

\section{A. Representation of Foreign Firms in Bulgaria}

Originally, after gaining political power, the present Bulgarian government excluded foreign companies and business firms from participation in the economic life of Bulgaria, liquidated all foreign commercial concerns, and prohibited any private person residing in the country from representing or concluding a foreign trade transaction on his own behalf or on behalf of a foreign commercial enterprise. $^{40}$ Even today, the legal position of foreign trading companies in Bulgaria remains legislatively unclear. Thus, it is impossible to state the general conditions for the admission of foreign firms to business activities on Bulgarian soil or for their admission to Bulgarian trade as partners of Bulgarian commercial enterprises. There is also no explicit legislation regarding such matters as a foreign' firm's direct contact with consumers, producers, and distributors; supervision of the distribution of products; advertising; and the study of the market's potential. Bulgarian writers in this field think that "there is no practical possibility" for a foreign firm to conduct permanently a commercial business on Bulgarian soil, ${ }^{41}$ but it is possible that individual transactions may be made. Only recently, pursuant to an Ordinance of November I9, I965, effective as of January I, I966, was the representative activity of a foreign firm in the country entrusted to the Government Economic Enterprise, BULET, Directorate for Foreign Representation, established on a separate economic account. ${ }^{42}$

After the expansion of the work in this area, there was need for the improvement of commercial activities on Bulgarian territory by foreign firms. Resolution

\footnotetext{
${ }^{38}$ PeNkov, supra note II, at 74 .

${ }^{30} 7 d$. at $74-75$.

10 Ordinance No. II4 Concerning the Commercial Representations of the Ministry of Trade and Supply, I948 DV No. 204; as amended I948 DV No. 267.

"PENKov, supra note II, at 75.

"Ordinance No. 225 of the Council of Ministers Concerning the Organization of the Work Relating to the Representatives of Foreign Firms in the Country of November 19, 1965; excerpts of text in PENKov, supra note II, at 225.
} 
No. II4 of the Committee for Economic Cooperation of April 4, xg69, repealing all other acts in this field, created independent bureaus for representation and commercial intermediation (türgovsko posrednichestvo) for foreign firms in the People's Republic of Bulgaria on the principle of internal economic account. ${ }^{43}$ These bureaus, eight in number in 1969 , are incorporated in the system of $I N$ $T E P R E D,{ }^{44}$ and the Ministry of Foreign Trade may establish additional bureaus as necessary. The primary task of these bureaus is to provide the necessary offices, commercial and technical personnel, and equipment for meeting the needs and requirements of the foreign firms or other authorized persons. The relations between the foreign firm (authorizer) and the bureau (representative) are regulated by a contract, and the latter receives remuneration for its services. All contracts for the representation of foreign firms in Bulgaria are to become operative only after their approval by the Ministry of Foreign Trade.

\section{B. Export-Import Licensing}

Export, import, and other foreign trade operations are subject to licensing by the competent Bulgarian authority, namely, the Ministry of Foreign Trade. This Ministry thus controls the flow of trade by issuing import and export permits covering individual transactions and authorizing the deliveries of goods. This system is governed by chapter IV of the Regulation Concerning the Organization, Administration, and Control of Foreign Trade of November 19, 1968.45 Similarly, the Ordinance for the Conclusion of Foreign Trade Transactions and for the Prohibition to Import and Export Foreign Currencies, Valuables, Objects, Printed Matter and Other Materials of January 14, I955, provides that foreign trade transactions shall be concluded by government foreign trade enterprises only after they have received written permission from the Ministry of Foreign Trade. ${ }^{48}$ Private persons living in Bulgaria, as well as domestic legal entities, are prohibited from concluding, or intermediating for the conclusion of, foreign trade transactions and from representing foreign firms. Private persons may represent foreign firms only at the International Trade Fair in the city of Plovdiv, Bulgaria, after receiving permission from the Ministry of Foreign Trade and the Ministry of Finance. The Bulgarian Foreign Trade Bank is under the obligation not to accept documents and not to make payments without being presented with a license issued by the Foreign Trade Ministry. The customs houses will likewise not permit the export or import of goods without the permission of this Ministry.

The manner in which licenses are issued is regulated by Order No. x04 of March 25, 1969 , of the Council of Ministers Concerning Import-Export Licenses. ${ }^{47}$

\footnotetext{
4s rg69 DV No. 3 r.

"As of April I, I969, the following independent bureaus for representation and commercial intermediation of foreign firms in the People's Republic of Bulgaria with the seat in Sofia had been established: Vitosha, Rila, Sredna Gora, Strandzha, Pirin, Murgash, Liulin, and Bilfarm.

${ }^{15} \S$ I0. $1968 \mathrm{DV}$ No. 90 .

I955 IPNS No. 4 .

${ }^{17}$ PENkov, supra note II, at 64 .
} 
In accordance with this Order, as of April $\mathrm{x}, 1969,{ }^{48}$ licenses for export and import must be obtained from the Ministry of Foreign Trade for all foreign trade transactions regardless of whether a socialist or capitalist country is involved. ${ }^{49}$ The requests of foreign trade organizations for the issuance of a license for export or import or for the performance of any other foreign trade transactions must be submitted in written form in accordance with fixed samples (obraztsi). The permission is valid for a specific period of time, and the customs houses require such documents before allowing the export or import of goods.

\section{Elements of, and Applicable Law in Regard to, Foreign Trade Contracts}

The Law on Foreign Trade of December 5, I969 (sections 17-20), and the Regulation implementing this law of Decomber 22, 1970 (sections 22-28), provide that foreign trade contracts may be concluded only with permission of the Ministry of Foreign Trade. ${ }^{50}$ Transactions without such permission are null and void (nedeistvitelni). Bulgarian foreign trade organizations which participate in the activities of business firms abroad also must secure approval for their transactions from the Ministry of Foreign Trade in the established manner. The Ministry may in some instances decide that certain transactions involving services of importance to public interest may require an auction or other form of open competition under conditions or rules prescribed by this Ministry. Furthermore, the Minister of Foreign Trade may always stop the execution of those contracts which might damage the interests of the State. If these are systematic and serious violations of the foreign trade discipline, he may even recommend that the Council of Ministers withdraw approval to engage in such activities.

The foreign exchange currency realized through foreign trade contracts is purchased by the Bulgarian Foreign Trade Bank. This Bank also sells the necessary valuta for the import and export of goods. Foreign trade organizations are obliged to keep all their free means in valuta, leva, and securities deposited in the Bulgarian Foreign Trade Bank, which for that purpose opens interest bearing accounts, current checking accounts, paying accounts, and so forth. ${ }^{51}$

Because there is no commercial code in Bulgaria nor any special provisions dealing exclusively with foreign trade contracts, the general provisions in this field must, as a rule, be applied. Thus, in accordance with section 2 of the Ordinance Concerning Contracts Involving the Execution of Deliveries and the Execution of Works and Services of May I8, I950, government and cooperative enterprises are under the obligation to conclude their contracts in written form regardless of who the other contracting party is. ${ }^{52}$ Oral contracts are excluded and non-

\footnotetext{
48 Text in Penkov, supra note $I I$, at 261 .

10 This act repealed Ordinance No. I44 of the Council of Ministers of August 2, 1966.

${ }^{\circ 0}$ For a detailed discussion of foreign trade contracts, see Garnefsky, Die Grundsätze des bulgarischen Aussenhandelsrechts, I2 OsTEUROPA-REchT 157 (1966).

${ }^{51}$ Penkov, supra note 8 , at 6.

${ }^{82} 1950$ DV No. 116.
} 
compliance with the requirement of a written contract renders it null and void (nishtozhen) for both parties, as specified in section 26, paragraph 2, of the Law on Contracts and Obligations of November 22, 1950..3 Section 33 of this Law further provides that the director of a government enterprise is authorized to represent it and to conclude contracts in its name and for its account as well. Thus, the signature of one person, the director of the government foreign trade organization or his representative, or the foreign trade agent abroad, is sufficient to validate a contract. All other formal aspects of a contract are left to the discretion of the parties. In the absence of agreement, the prevailing principle is locus regit actum.

A major problem is the legal status of a contract concluded with foreign firms without a license issued by the competent Bulgarian authorities, because, as the Bulgarian spokesman in this field, Penko Penkov, puts it: "it has a tremendous practical, political, and legal importance."54 According to section to of the Regulation Concerning the Organization, Administration, and Control of Foreign Trade of November 19 , $x 968$, foreign trade enterprises may conclude trade contracts only after obtaining permission from the Ministry of Foreign Trade. ${ }^{55}$ By its nature, as Bulgarian legal writers put it, this provision restricts the legal capacity of such enterprises, that is, they are legal entities with limited capacity to conclude transactions (ogranichena deesposobnost). ${ }^{56} \mathrm{~A}$ contract made without permission is voidable (unishtozhaem). If no one questions the defect, it will be given legal effect. A voidable contract may be challenged only by the Bulgarian foreign trade enterprise since the defect affects its legal capacity. Therefore, a Bulgarian foreign trade enterprise has the right to repeal the contract on the basis of this defect. On the other hand, the foreign partner must regard the contract as binding on the basis of the principle of pacta sunt servanda. If the Bulgarian enterprise does not reveal the fact that it needs the approval of the Ministry of Foreign Trade and a later reference to this defect causes the foreign partner damage, the partner may seek compensation for those damages by referring to the overreaching in the contracting (culpa in contrahendo) on the part of the Bulgarian foreign trade enterprise.

Bulgarian private international law makes no provision regarding the question of the law applicable to Bulgarian foreign trade, and the Bulgarian civil code does not provide an answer. Furthermore, Bulgaria did not ratify the Hague Convention on the Uniform Law on the International Sale of Goods of July r, I964. The question of the choice of applicable law is also treated in the European Convention on International Commercial Arbitration of April 21, I96I (Geneva), ${ }^{57}$ to which

\footnotetext{
${ }^{\mathrm{s}} 1950$ DV No. 275 , as amended.

"Penkov, supra note II, at 65.

Ig68 DV No. 90.

${ }^{38}$ PENKov, supra note II, at 65.

${ }^{67} 484$ U.N.T.S. 364 , 374. See also the Agreement Relating to Application of the European Convention on International Commercial Arbitration, Dec. 17, 1962. Io European Yearbook 579 (1962).
} 
Bulgaria is a party. According to article VII(I) of this Convention "the parties shall be free to determine, by agreement, the law to be applied by the arbitrators to the substance of the dispute." Therefore, this question must be resolved by the contract itself. A dispute may arise when enterprises do not properly dispose of this question in their contracts, ${ }^{\text {5s }}$ and in that case Bulgarian legal writers are of the opinion that the provisions of the Bulgarian law should apply, or the legal system of the supplier, ${ }^{59}$ or a third neutral legal system. The question of the parties' autonomy to determine the applicable law (lex electa, lex voluntaris) is irrelevant since under Bulgarian law one can speak only of administrative discretionary power on the part of the director which is given to him in the field of foreign trade on the basis of the provisions of a constitutional, administrative, and financial nature, since this is within the jurisdiction of a government economic organization. Section 9, paragraph $\mathrm{I}$, of the Law on Contracts and Obligations provides that "the parties may freely determine the contents of the contract, as long as they do not contradict the law, the government economic plan and the rules of the socialist society." Section 90 of the Edict on the Merchant Marine of October 2, I953, explicitly declares that in the contracts dealt with by it the parties may include clauses regarding the application of foreign laws only in the cases in which the Edict permits deviation from the rules established by it. ${ }^{61}$ As Vladimir Kutikov, an authority in the field of Bulgarian private international law, states "[i]n a socialist planned economy, as is ours, export-import transactions are possible only within the government economic plan." ${ }^{\text {22 }}$ Section 89, paragraph 8, of the Edict on the Merchant Marine also provides that

in the cases when, pursuant to this Section, the provisions of this Edict have an application, the judicial authorities of the People's Republic of Bulgaria may apply the foreign laws, as long as the latter do not contradict the fundamental principles of the state regime of the People's Republic of Bulgaria.

If the parties failed to choose the applicable law, the Bulgarian law gives no answer-and the question is left to the court. Legal writers think that either lex loci contractus or lex loci solutionis is applicable. ${ }^{63}$

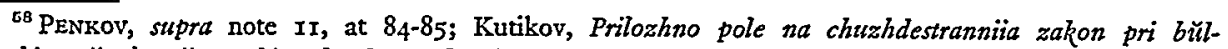
garskite vĭnshnotiurgouski pokupko-prodazhbi (Scope of Application of Foreign Law in Regard to Bulgarian Foreign Trade Purchases and Sales), Pravin vŭprosi na vŭnshimata tŭrgovila na N.R. Bŭlgarita 303-22 ( 1963 ).

${ }^{\circ 0} \mathrm{~A}$ principle accepted by the COMECON countries and the Hague Convention.

${ }^{\circ 0}$ See also the article by Tsoniu Damianov, Izbor na prilozhimiia zakon (Choice of Applicable Law), I8 Vŭnshna Tŭrgovira No. 3 ( 1970 ), at $25-29$, as well as his survey of judgments of the Bulgarian Foreign Trade Arbitration Tribunal dealing with this problem, I7 Vŭnshns Tŭrgoviı No. 3 (I969), at 25-27; 16 VŭNshna Türgovila No. I (I968), at 27-29; I6 Vŭnshina Tŭrgovila No. 2 (I968), at 24-25.

01 1953 IPNS No. 79.

${ }^{63}$ Kutikov, supra note 58 , at 309 .

${ }^{03}$ I. Altunov, Mezhounarodno-chastnopravnata sistema na N.R. Bŭlgarita (Private InterNational Law System of the P.R. of Bulgaria) 303 (I955).
} 
IV

\section{Foreign Trade Arbitration}

\section{A. Foreign Trade Arbitration Tribunal}

For cases concerning foreign trade that are submitted to arbitration, the present government has set up, apart from the judicial system, a special permanent arbitral institution. On the basis of the Code of Civil Procedure of February 2, I952 (section 9, paragraph I) ${ }^{64}$ and the Edict on the Merchant Marine of October 2, 1953 (section 85), as well as the Resolution No. 109 of February $4,1952,05$ the Council of Ministers approved the Statute on a Foreign Trade Arbitration Commission at the Chamber of Commerce in Sofia, Ustav na Vünshnotiurgovskata Arbitrazhna Komisiia pri Türgovskata Palata. ${ }^{68}$ This Commission, which has its seat in Sofia, adopted its Rules of Procedure on February I9, I952. ${ }^{67}$ On April 28, I969, the Executive Board of the Chamber of Commerce renamed it the Arbitration Tribunal (Arbitraztien Süd) and approved the new Regulations of the Arbitration Tribunal, thus repealing the preceding Statute and Rules of Procedure. ${ }^{68}$ According to the official government publication, Vünshna Türgoviia, this judicial body adjudicated over 630 cases during the period $1952-1969 .{ }^{69}$

The Tribunal is competent to hear disputes involving foreign trade arising (a) between Bulgarian and foreign enterprises, firms and persons and (b) between foreign companies. ${ }^{\mathbf{7 0}}$ However, the jurisdiction is limited to disputes in which the parties have agreed to submit their differences to this Tribunal for settlement or in which there is a treaty agreement between the Bulgarian government and the government of a foreign country providing for the submission of such differences to the Bulgarian Foreign Trade Arbitration Tribunal.

The proceedings are conducted in the Bulgarian language, and the plaintiff is obliged to deposit the fees of the trial in an amount fixed by a tariff. The deciding body is composed of three arbiters after each party has chosen an arbitrator from among the members of the Tribunal. Upon agreement of the parties only one arbitrator may decide the case. Not later than five days from the election of the

\footnotetext{
${ }^{64} 1952$ IPNS No. I2.

${ }^{65}$ See note $3 \mathrm{I}$ supra.

${ }^{\circ 0}$ For English text, see L. Kos-Rabcewicz-Zubrowski, East European Rules on the VAlidity of International Commercial Arbitration Agreements 127 (I970).

${ }^{67}$ See ig67 Bulletin of the Ministry of Foreign Trade Nos. 7-8; for English text, see KosRABCEWICZ-ZuBKowsK, supra note 66 , at 128 .

${ }^{88}$ See 1969 Bulletin of the Ministry of Foreign Trade No. 9.

${ }^{60} 17$ VŭNSHNA Tŭrgovira No. 8 (1969), at 27.

${ }^{70}$ According to a report published in the periodical Vŭnsuss Tüncovirs, the Forcign Arbitration Commission tried twclve cases within its first year of existence. In only one case was the plaintiff to a suit a Bulgarian foreign trade enterprise. In all the other cases Bulgarian forcign trade enterprises were defendants. I VŭNshis Tŭrgovira No. 3 (1953), at 10. Kos-RABcewicz-Zubkowski, stupra note 66, reports four cases of a recent time. The Bulgarian legal journal, Pravna MisŭL, reports another case between a Bulgarian foreign enterprise and a Panamanian firm before an Arbiter in London and the Bulgarian Supreme Court, first civil chamber, Decision No. 2268/197r. 15 Pravis Mısŭ. No. 6 (I97r), at $89-9$ r.
} 
two arbitrators, the latter must choose a chairman-arbitrator. If one of the parties does not choose an arbitrator, the Chairman of the Tribunal appoints one. The parties may, at their own discretion, appoint representative attorneys, who may be either Bulgarian or foreign nationals, to defend their interests at the hearing of the dispute. If one of the persons participating in the case does not speak Bulgarian, an interpreter is appointed. At the hearing of the case, the Foreign Trade Arbitration Tribunal collects a fee to cover the costs of the procedure, the maintenance of the Tribunal, the citation of witnesses, experts, and so forth. The amount of the fee is determined by the Tribunal during the hearing. The decision is taken by a majority vote. It is final and not subject to appeal.

\section{B. Execution of Arbitral Decisions}

Arbitral decisions do not in themselves lead to compulsory execution. The interested party must ask the competent civil court to provide for execution. This is done by the Sofia City Court in accordance with section 237(a) of the Code of Civil Procedure in' connection with section 58, point 2, of the Regulation of the Arbitration Tribunal at the Bulgarian Chamber of Commerce. ${ }^{71}$ In connection with the recognition and execution of foreign arbitral decisions, Bulgaria ratified on October 10, 196r, ${ }^{72}$ the Convention on the Recognition and Enforcement of Foreign Arbitral Awards of June Io, $195^{8}$ (New York), ${ }^{73}$ and on March I3, $1964,{ }^{74}$ the European Convention on Foreign Trade Arbitration of April 2I, I96r (Geneva). ${ }^{75}$ It must be pointed out here, however, that Bulgaria is not a party to the General Protocol of Arbitration Clauses of September 24, 1923, or the Geneva Convention on Execution of Foreign Arbitral Decisions of September 26, I927.

\section{V}

\section{Foreign Trade Treaties and Agreements}

The commercial relations of Bulgaria with the countries of the Communist bloc in Europe are closely regulated under the auspices of the COMECON (Council for Mutual Economic Assistance). These relations with the countries of the so-called "third world," Asia, Africa and Latin America, are expanding rapidly. ${ }^{76}$ While until I96r, Bulgaria had business arrangements only with two states in Latin America (Argentina since 1947, Uruguay since 1956), today Bulgaria entertains such relations with sixteen of the nineteen Latin American countries. ${ }^{77}$ The most recent

\footnotetext{
${ }^{71}$ For an analysis, see also Dichev, Problemi na vŭnshno-türgouskiia arbitrazh v Bülgarïa (Problems of the Foreign Trade Arbitration in Bulgaria), I7 VŭNshNs Tŭrgovis No. 2 (1969), at 22-24.

${ }^{73}$ 196I DV No. 57; text in Bulgarian language, I965 DV No. 2.

${ }^{72} 330$ U.N.T.S. 3.

${ }^{74}{ }_{1964}$ DV No. 23; text in Bulgarian language, 1964 DV No. 57.

${ }^{78}{ }_{4} 84$ U.N.T.S. 349 .

${ }^{70}$ Betsinski, Iznosüt na promishleni izdeliia predpostavka za razshiriavane na vŭnshnata türgoviia na N.R. Bülgariia (The Export of Industrial Goods-Basis for Expansion of the Foreign Trade of the P.R. of Bulgaria), rg Vŭnstns Tŭrgovins No. 4 (1971), at 7-10.

${ }^{77}$ Anastasov, Türgoviiata na N.R. Bülgaria süs stranite ot Latinska Amerika (The Trade of the
} 
agreement is that with Columbia, signed in Bogota on June 15 , I971, and ratified by the Bulgarian government on August 2I, $9972 .{ }^{78}$

Major efforts are now being made to initiate trade relations with the capitalist countries and the Western world, since economic cooperation with non-socialist systems is considered a vital necessity for the development of the Bulgarian economy. Bulgaria's first commercial agreement with a capitalist country involving international trade was that with Switzerland of December 4, I946, followed by agreements with Austria and Belgium in $19477^{79}$ Problems clearly remain, however. As Professor Zhivko Stalev, the spokesman of the Bulgarian government in the field of foreign trade law, puts it, "as far as [Bulgaria's] foreign trade relations with non-socialist states are concerned, [Bulgaria's] legal system does not contain provisions for their proper regulation."80 Luchezar Avramov, the Bulgarian Minister of Foreign Trade, Candidate-Member of the Politbureau of the Central Committee of the Bulgarian Communist Party and Deputy-Chairman of the Council of Ministers, wrote in I97x that the capitalist countries still exercise a discriminatory policy in the field of foreign trade toward Bulgaria. ${ }^{81}$ He further stated that during the Sixth Five-Year Economic Plan of the People's Republic, the exchange of goods with the capitalist countries could develop mainly in regard to imports from these countries and, for balance reasons, at a slow pace. Also the present administration of the United States, in an effort to develop the East European area as a U.S. market place, has supported a series of legislative moves to liberalize export controls, remove restrictions on credit financing, and extend most-favored-nation trade status selectively. Bulgaria, with its newly awakened consumer interests and expanding industrial needs, has significantly increased its trade with the West in the r97o's.

In order to encourage development of commercial relations, especially beyond the Communist bloc, Decision No. 257 of the Council of Ministers of June 30, I964, Concerning the Export of Machines and Equipment to Capitalist Countries on Firm Credits permits the granting of credit "for a period of up to 5 years" through the Bulgarian Foreign Trade Bank with the limitation that it "may not exceed $30 \%$ of the plan for export of machines and equipment to capitalist countries." 82 Furthermore, the Ordinance for Export Premiums and Export Taxes of December 18, 1970, provides that export premiums are granted to economic organizations by the State for fostering the export of greatly desired goods, for the increase

\footnotetext{
$\overline{P . R . ~ o f ~ B u l g a r i a ~ w i t h ~ t h e ~ C o u n t r i e s ~ o f ~ L a t i n ~ A m e r i c a), ~} 19$ VŭNsHNA Tŭrgovira No. 6 (1971), at 12-14.

${ }^{78}$ I972 DV No. 77.

${ }^{70}$ Penkov, Vünshnotürgovski otnosheniia na N.R. Bülgarïa s razvitite kapitalisticheski strani (Foreign Trade Relations of the P.R. of Bulgaria with the Developed Capitalist Cotsntries), I7 VünsHNA Tŭ́Rgovira No. 8 (I969), at I5.

${ }^{80}$ Stalev, supra note 9 , at $\mathrm{II}$.

${ }^{81}$ Avramov, Postizheniia i perspektivi na vĭnshnata türgoviia na N.R. Bülgariia (Achievements and Perspectives of the Foreign Trade of the P.R. of Bulgaria), 19 Vŭnsins Tŭroovin No. 3 (1971), at 2-5.

82 Penkov, supra note $\mathrm{II}$, at 263.
} 
of foreign currency income, and for the expansion of foreign trade contacts of the country. ${ }^{83}$ The necessity for export premiums is, however, determined under the Uniform Economic Plan and are granted by the Ministry of Foreign Trade. Export taxes are used for limitation of the export of industrial goods when it is not expedient to exceed the limit determined by the plan's volume for export.

A survey of the Bulgarian official law gazette, Dürzhaven Vestnik, reveals that Bulgaria has trade relations with the following capitalist countries: Canada (October 8, I963, Ottawa); Benelux (July I6, I965, Brussels); Denmark (December 5, I965, Copenhagen); Italy (September 20, rg66, Rome); Japan (February 28, r970, Sofia); Sweden (June 13 , I966, Stockholm). Furthermore, the collection of foreign trade agreements with "non-socialist" countries (covering the period after the establishment of the present government in I944 until I967) lists thirty-six foreign trade agreements. ${ }^{84}$ These include agreements with the following European countries: Austria (April 3, I963, Sofia); Benelux (July I6, I965, Brussels); Germany (May 30, 1956, Bonn); Greece (July 9, 1964, prepared in Sofia, signed in Athens); Italy (December 10, 1965, Sofia); Norway (December 20, 1965, Oslo); Turkey (February 23, I955, Ankara); Finland (October 4, r967, Sofia); France (March 23, Ig66); Sweden (June I3, rg66, Stockholm).

A general survey of the foreign trade agreements of Bulgaria with "non-socialist" countries in Europe, Asia, Africa, Australia, and Latin America reveals that while their texts vary slightly, the following common features may be pointed out. (I) The trade is to be conducted in accordance with the export-import regulations effective in each of the contracting parties' countries. (2) Each party (a) shall enjoy the status of a most-favored-nation on the basis of the principle of reciprocity, when the other contracting party is a West European country, ${ }^{85}$ or (b) shall conduct trade on the basis of equality (ravenstvo) and mutual interest (vzaimna izgoda), when the opposite partner is a country outside the European area. (3) Both parties assume the obligation to issue export-import licenses in the most favorable terms and manner possible. (4) As a rule, each agreement provides for the creation of a joint commercial commission with the tasks of executing the agreement, eliminating difficulties, facilitating the execution, considering certain problems, and recommending useful changes.

\section{Conclusion}

The change in the form of government which took place in Bulgaria in the aftermath of World War II brought with it profound changes in the foreign trade

\footnotetext{
${ }^{83} 1970$ DV No. 100.

8t See generally P. Penkov, I-3 Tŭrgovski dogovori Na [N.R.] Bŭlgarira (Trade Treaties [oF THE P.R.] of BuLgaria) ( $x 969-7 x)$.

${ }^{85}$ In his article on the foreign trade relations of Bulgaria with the capitalist countries, such as Canada, Australia, New Zealand, Austria, Iceland, Spain, Finland, France, Switzerland, and others, Penko Penkov states that "Bulgaria enjoys, on the basis of reciprocity, the clause of the most favored nation." I7 Vŭnstres Tŭrgovirs No. 8 (I969), at I5.
} 
law. The theoretical foundation for this change was the socialist principle of state monopoly of foreign trade. This principle does not mean that the state alone participates in foreign trade but that control of foreign trade is a sovereign right of the state and that foreign trade is merely an instrument of policy in the management of the national economy. Expanded economic relations with non-socialist nations is considered to be of vital importance to the economy of the People's Republic of Bulgaria, and rapid expansion is already taking place with nations of the "third world." Further expansion of trade with the Western capitalist countries will depend both on the needs of the developing Bulgarian economy and the demand for new markets for the products of the capitalist countries.

\section{Selective Bibliography}

I. Altunov, Mezhdunarodno-chastnopravnata sistema na N.R. Bŭıgaruia (Private Internattonat Law System of the P.R. of Bulgaria) (r955).

Damianov, Izbor na prilozhimiia zakon (Choice of Applicable Law), i8 Vŭnshna TŭrGOVIIA No. 3 ( 1970$)$, at 25-29.

Dichev, Problemi na vŭshno-tŭrgovskiia arbitrazh v Bülgariia (Problems of the Foreign Trade Arbitration in Bulgaria), I7 VŭNshNa Tŭrgovira No. 2 (1969), at 22-24.

M. Domke, Internattonal Trade Arbitration. A Road to World-Wide Cooperation (I958).

Garnefsky, Die Grundsätze des bulgarischen Aussenhandelsrechts, I2 OsTrUROPA-Rzcht 157 ( 1966$)$.

B. Ivanov \& I. Laskov, Sbornik ot osnovini normativni aktove na vŭNshnata tŭrgovita na N.R. Bŭlgarita (Collection of Basic Legal Acts on Foreign Trade op THE P.R. OF BuLGARIA) (r 97 r).

Khristoforov, Dürzhavniiat monopol na vünshnata türgoviia na N.R. Bülgariia (Government Monopoly of Foreign Trade in the P.R. of Bulgaria), PravnI vŭpnosi NA vŭnshnata tŭrgovita na N.R. Bŭrgarita (Legal Problems of the Foreign Trade OF THE P.R. of BuLGarta) 5-33 (I963).

Khristoforov, Praven statut i funktsii na tŭrgovskite predstavitelstva na N.R. Bülgariza v chuzhbina (Legal Status and Functions of the Trade Representatives of the P.R. of Bulgaria Abroad), PravNi vŭprosi na vŭNSHNata tŭRgovira Na N.R. Bŭrgaria $35-50$ (Ig63).

K. Khumbadzhiev, Arbitrazhna praktiKa Na vŭNshnotŭRgovsKata arbitrazhina komisila pri Bŭlgarskata Tŭrgovska Palata, i954-x966 (Arbitral Practice of the Foreign Trade Arbitration Commission at the Bulgartan Chamber or Commercr, I954-I966) (I967).

Kojouharoff, Chronique de jurisprudence de la Cour arbitrale près la Chambre de commerce bulgare, 94 Journai du Droit InTERnattonal 152, 159-60 (1967).

L. Kos-Rabcewicz-Zubkowski, East European Rules on the Validity of International Commercial Arbitratton Agreements (i97o).

V. Kutikov, Mezhidunarodno chastno pravo na N.R. Bŭtgarita (Private InternatTonal LaW of the P.R. of Bulgaria) (1958).

Kutikov, Prilozhno pole na chuzhdestranniia zakon pri bülgarskite viunshnotŭrgovki po. kupki-prodazhbi (Scope of Application of Foreign Law in Regard to Bulgarian Foreign Trade Purchases and Sales), Pravni vŭprosi Na vŭnshinata tŭrgovira Na N.R. BŭLGARIIA 303-32 (x963). 
Lukanov, Problemi na turgovitata iztok-zapad (Problems of the East-West Trade), I6 Vŭnshna Tŭrgovira No. I (rg68), at 8-ro.

P. Penkov, I-3 Tŭrgovski dogovori na [N.R.] Bülgarita (Trade Treaties of the [P.R.] OF BULgaRIa) (I969-7I).

P. Penkov, Vŭnshna tŭrgovita na N.R. Bŭlgarita. Zakoni, postanovlenita, I DR. (Foreign Trade of the P.R. of Bulgaria. Laws, Regulations, etc.) (x969).

S. Pisar, Coexistence and Commerce: Guidelines for Transactions Between East AND WeST (I970).

Pravin vŭprosi na vŭnshanata tŭrgovita na N.R. Bŭlgarita (Legal Problems of the Foreign Trade of the P.R. of Bulgaria) (Ig63).

Sipkov, Foreign Trade Chamber of Commerce and Foreign Trade Arbitration Commission Under Communist Government, 4 Highlights of Current Legislation and Activities IN Mid-Europe No. I2 (I956), at 423-34.

Z. Stalev, Commission d'arbitrage d'affaires commerctales près de la Chambre de commerce de la Répubitque Populatre de Bulgarie (I954).

Z. Stalev, Foreign Trade Arbitration Committee (1954).

Stalev, Vünshnotürgovska arbitrazhna komisiia pri Türgovskata palata v. N.R. Bülgariia (Foreign Trade Arbitration Commission at the Chamber of Commerce in the P.R. of Bulgaria), 2 Goshnik na Sofissira UnIversiter, IuRIdicheski Fakultet (I954).

Stalev, Pravo na vŭnshnata tŭrgoviia (The Law of Foreign Trade), I5 Vŭnshna Tŭngovira No. 6 (1967).

K. Stanke, Der Handel mit dem Osten (ig68).

L. Vasilev, Grazhdanszo pravo na N.R. Bŭlgarita (Crvil Law of the P.R. of Bulgaria) (3d ed. 1956$)$. 